\title{
Preface \\ X International Scientific and Technical Conference «Polytransport systems» (PTS-2018)
}

$\mathrm{X}$ International Scientific and Technical Conference «Polytransport systems» (PTS-2018) is held on 15-16 November 2018 at Siberian Transport University (Novosibirsk, Russia).

\section{Program and Scientific Editorial Board: \\ Chairman}

Aleksey L. Manakov, rector of Siberian Transport University, Dr. Tech. Sc. (Novosibirsk, Russia)

Key members:

Andrey D. Abramov - Dr. Tech. Sc., Prof., vice-rector for research, Prof. of the Department of Technologies of transport machine-building and exploitation of machines, Siberian Transport University (Novosibirsk, Russia), Chief Editor

Aleksander K. Golovnich - Dr. Tech. Sc., Prof., head of the Department of Transportation hubs, Belarusian State University of Transport (Gomel, Republic of Belarus)

Taisiya V. Shepitko - Dr. Tech. Sc., Prof., head of the Institute of track, construction and structures, Russian University of Transport (Moscow, Russia)

Vladimir V. Chervov - Dr. Tech. Sc., Prof., head of the Laboratory for mining mechanization, Chinakal Institute of Mining of the Siberian Branch of the Russian Academy of Sciences (Novosibirsk, Russia)

Vladimir N. Efimenko - Dr. Tech. Sc., Prof., Department of Automobile Roads, Tomsk State University of Architecture and Buildin (Tomsk, Russia)

Aleksander L. Isakov - Dr. Tech. Sc., Prof., head of the Department of Railway and highway surveying and design engineering, Siberian Transport University (Novosibirsk, Russia)

Evgeniy V. Boyarkin - Dr. Tech. Sc., Prof., Department of Electrical engineering, diagnostics and certification, Siberian Transport University (Novosibirsk, Russia)

Valeriy I. Khabarov - Dr. Tech. Sc., Prof., Department of Information technologies in transport, Siberian Transport University (Novosibirsk, Russia)

Vladimir I. Medvedev - Dr. Tech. Sc., Prof., Department of Life safety, Siberian Transport University (Novosibirsk, Russia) Aleksander A. Klimov - Cand. Tech. Sc., Assoc. Prof., Department of Railway stations and junctions, Siberian Transport Univesity (Novosibirsk, Russia)

Evgeniy A. Grigoryev - Cand. Econ. Sc., Assoc. Prof., deputy dean of the faculty of Water transport management, Siberian State University of Water Transport (Novosibirsk, Russia)

Petr K. Rybin - Cand. Tech. Sc., Assoc. Prof., Department of Department of Railway stations and junctions, Emperor Alexander I St. Petersburg State Transport University (Saint Petersburg, Russia)

Sergei A. Maksimov - Cand. Tech. Sc., Assoc. Prof., president of Siberian Union of Transport, Freight Forwarders and Logistics Employees, Department of Systems analysis and project management, Siberian Transport University (Novosibirsk, Russia)

Diana Yu. Grishkova - Cand. Tech. Sc., Assoc. Prof., Department of Freight operation and rolling stock, Siberian Transport University (Novosibirsk, Russia)

Olga Yu. Chuykova - Cand. Tech. Sc., Assoc. Prof., Department of Freight operation and rolling stock, Siberian Transport University (Novosibirsk, Russia)

Maksim V. Korneev - Cand. Tech. Sc., Assoc. Prof., Department of Freight operation and rolling stock, Siberian Transport University (Novosibirsk, Russia)

Konstantin V. Zheldak - Cand. Tech. Sc., Assoc. Prof., Department of Freight operation and rolling stock, Siberian Transport University (Novosibirsk, Russia)

Nikolay A. Maslov - Cand. Tech. Sc., Assoc. Prof., Department of Mechanization of railway, loading/unloading and construction work, Siberian Transport University (Novosibirsk, Russia)

Evgeniy S. Tenitilov - Cand. Tech. Sc., Assoc. Prof., Department of Electrical engineering, diagnostics and certification, Siberian Transport University (Novosibirsk, Russia)

Sergey P. Sarychev - Cand. Tech. Sc., Assoc. Prof., Department of Information technologies in transport, Siberian Transport University (Novosibirsk, Russia)

X International Scientific and Technical Conference «Polytransport systems» is an interdisciplinary event dedicated to a wide range of relevant research topics such as problems of transport projects implementation: transport infrastructure facilities, transportation management and economy; infrastructure-related projects; modern systems of maintenance and repair of vehicles and rolling stock; non-destructive testing and technical diagnostics; intellectual control systems for transport; transportation safety; human resource-related safety aspects, etc.

The conference is held for the purpose of supporting research activities among research staff, specialists, young researchers, $\mathrm{PhD}$ students and undergraduate students by discussing relevant problems and research outcomes. The number of the conference participants has reached 240 people from 25 research and educational institutions, with 170 oral contributions.

The Chairman of the program and scientific editorial boards expresses his gratitude to the members of the organizational committee and secretariat of the event and all employees who help provide efficient work of the conference. Organizers acknowledge participants for their important contribution in the form of their oral reports and the present proceedings.

Editor of the Proceedings Volume, Prof. Andrey D. Abramov, Dr. Tech. Sc., Prof. Novosibirsk, September, 2018 